\title{
An updated check-list of Italian amphibians and reptiles
}

\author{
Roberto Sindaco ${ }^{1 *}$, Edoardo Razzetti ${ }^{2}$
}

\begin{abstract}
This paper represents an update of the list of Italian amphibians and reptiles published 15 years ago by Razzetti et al. (2006) and of the checklist published in 1993 by the late Benedetto Lanza. At present, the Italian herpetofauna includes 100 species (41 amphibians and 59 reptiles) and an amphibian taxon of hybrid origin. Seven species and one subspecies are allochthonous and became naturalized within the last century. Since the last published list, a new species has been described (Vipera walser), five taxa have been raised to species rank (Salamandrina perspicillata, Speleomantes sarrabusensis, Zootoca carniolica, Malpolon insignitus and Natrix helvetica) while three taxa have been downgraded to subspecies. All the relevant taxonomic changes based upon new research have been discussed, including tentative revisions and controversial taxa. Nine species reported or listed dubitatively in Lanza's 1993 list are excluded here.
\end{abstract}

Key words: Amphibians, Italy, reptiles, subspecies, taxonomic inflation, taxonomy. liani.

Riassunto - Una check-list aggiornata degli anfibi e dei rettili ita-

Gli autori presentano un aggiornamento dell'erpetofauna italiana rispetto all'elenco pubblicato 15 anni or sono da Razzetti et al. (2006) e alla lista di Benedetto Lanza del 1993. L'erpetofauna italiana è costituita da 100 specie (41 anfibi e 59 rettili) e un taxon di anfibi di origine ibrida. Sette specie e una sottospecie sono alloctone naturalizzate nel corso degli ultimi 100 anni. Da quando è stato pubblicato l'ultimo elenco italiano è stata descritta una nuova specie, Vipera walser, cinque taxa, Salamandrina perspicillata, Speleomantes sarrabusensis, Zootoca carniolica, Malpolon insignitus e Natrix helvetica, sono stati elevati al rango di specie e altri tre taxa sono stati portati al rango di sottospecie. Tutte le variazioni tassonomiche sono discusse alla luce delle più recenti evidenze scientifiche, così come sono presentate le differenti opinioni degli autori al riguardo di taxa la cui validità è ancora oggetto di dibattito. Nove specie riportate per il territorio italiano o elencate in modo dubitativo nell'elenco del 1993 sono qui escluse.

\footnotetext{
${ }^{1}$ Istituto per le Piante da Legno e l'Ambiente, Corso Casale 476, I-10132 Torino, Italia.

https://orcid.org/0000-0002-2590-9603

${ }^{2}$ Kosmos - Museo di Storia Naturale, Università degli Studi di Pavia, Piazza Botta 9/10, 27100 Pavia, Italia.

E-mail: edoardo.razzetti@unipv.it

http://orcid.org/0000-0001-5638-7935

* Corresponding author: rsindaco@gmail.com

(C) 2021 Roberto Sindaco, Edoardo Razzetti
}

Received: 2 March 2021

Accepted for publication: 12 June 2021

Online publication: 29 October 2021
Parole chiave: Anfibi, inflazione tassonomica, Italia, rettili, sottospecie, tassonomia.

\section{INTRODUCTION}

"Checklists of species are invaluable tools in the fields of natural science. They serve to consolidate our level of knowledge and at the same time reveal areas in need of further investigation" (Parenti \& Randall, 2000).

The last checklist of the Italian herpetofauna (with taxonomic remarks) dates back to fifteen years ago (Razzetti et al., 2006) and represents the updating of previous lists (e.g. Lanza in Amori et al., 1993). Since then, several taxonomic changes have occurred and markedly modified the picture of the species distributed in Italy.

Some of the name changes are updates resulting from taxonomic revisions, while some others represent just nomenclature amendments. A few species occurring in areas adjacent to the study area and included in previous Italian checklists have been excluded, whereas a number of alien taxa are now naturalised in the country.

However, most of the changes are the result of the considerable contributions given by the publication of phylogenetic and phylogeographic studies. The use of DNA in phylogenetic reconstructions allowed to distinguish cryptic taxa that were difficult to identify on the sole morphological basis, thus significantly increasing the number of recognized species (e.g. in the genera Bufotes, Hyla, Anguis, etc.), and the knowledge on the genetic structure of the various taxa, with an impact on taxonomy, biogeography and conservation biology.

In recent decades, on a global level, the number of recognized taxa (including amphibians and reptiles) have increased to such an extent to speculate about a "taxonomic inflation" (Isaac et al., 2004). In support of this, a recent study on Eurasian vipers recognizes "15 taxa as valid species, three taxa which likely represent species complexes, 17 taxa of doubtful validity as species, and five taxa for which species status is maintained but further research is highly recommended to assess taxonomic arrangements" (Freitas et al., 2020).

The "taxonomic inflation" might be due to the tendency of recognizing as species the clades emerging from phylogenetic trees, and to the fact that the description of a "new" species has a greater "impact" than a subspecies. 
Moreover, when negotiating with agencies deciding on conservation policies and their funding, species-targeted interventions are more likely to be funded than those targeting subspecies or local populations. This encourages the elevation to species rank of populations that need protection, regardless of whether there is scientific support for this status (Isaac et al., 2004). Although the conservation aims are acceptable, in our opinion the vulnerability of a not very diversified population cannot be the criterion for elevating it to a species.

To estimate species boundaries more precisely, many authors adopt an "integrative taxonomy" approach (Dayrat, 2005), which combines "different lines of evidence (e.g. genetic, morphological, ecological) and methodologies (e.g. phylogenetic inference, ordination methods, ecological modelling) to objectively identify taxa".

Other than increasing knowledge about cryptic taxa and the genetic structure of species, phylogenetic studies have challenged the idea of "rigid" taxonomic categories of genus, species and subspecies in view of the continuum of differentiation that we observe in nature. Modern genetic studies not only provide elements of classification (taxa) but also hypotheses on the clades (lineages) and the phylogeny (relations between clades); therefore, the traditional taxonomic categories (e.g. taxa, genera, species) are often replaced by the terms "clades", "lineages" and "Evolutionarily Significant Units" (ESUs).

Above all, the concept of subspecies has fallen into disuse, as currently many studies tend to raise subspecies to a specific rank (especially if geographically allopatric) if they show some genetic differentiation, even small, as long as it is statistically supported. On the other hand, many "classic" subspecies, described based on morphological variations or discrete distribution ranges (in particular the micro-island subspecies) have not been supported by the results of genetic studies and are therefore to be considered synonyms. Nonetheless, it is believed that the taxonomic category of subspecies is very useful, not only for describing the geographical peculiarities of populations, but also for highlighting the stages of incomplete speciation, which can be reversible when two only partially differentiated populations come into contact; the use of subspecies is beneficial both for communication among scientists and for conservation (Kindler \& Fritz 2018).

\section{MATHERIALS AND METHODS}

This checklist is an updated picture of all the amphibians and reptile taxa naturally occurring, or introduced and naturalized within the Italian political territory. Two species of marine turtles have been listed here despite limited records of vagrant individuals in the study area. The checklist includes also several taxonomic and nomenclatural remarks about status and distribution of many taxa.

The present paper represents the subjective point of view of the authors. We are well aware that the recognition of a taxon is a scientific hypothesis and not an absolute truth, and therefore a taxon can, in some cases, be assessed differently based on the knowledge and opinions of each author.
At the species level, we mostly adopted the published results of the Taxonomic Committee of the Societas Europaea Herpetologica (Speybroeck et al., 2020), composed of 12 international experts. Any opinions diverging from those of the Taxonomic Committee of the S.E.H., as well as all the discrepancies with respect to the previous Italian check-lists (Lanza in Amori et al., 1993; Razzetti et al., 2006), are explained in the notes.

As for the subspecies, not covered by Speybroeck et al. (2020), we generally adopted geographically isolated populations (populations with disjoint or island ranges) showing some genetic differentiation, provided statistically supported, or populations of those "semi-species" showing restricted introgression areas.

Moreover, we refrained to list subspecies of highly variable species for which the available studies have only tentatively revised the infraspecific taxonomy (e.g. Podarcis siculus, P. muralis).

\section{DISCUSSION}

According to the present checklist, the Italian herpetofauna is represented by 100 species (41 amphibians and 59 reptiles) and an amphibian taxon of hybrid origin (Pelophylax kl. esculentus). Five species are marine turtles, of which only Caretta caretta breeds regularly (although in relatively small numbers) on Italian beaches; Dermochelys coriacea and Chelonia mydas are regularly observed along Italian coasts, while Lepidochelys kempii and Eretmochelys imbricata occur in the Mediterranean only with vagrant individuals.

Six species and a subspecies are aliens naturalized within the last century (Lithobates catesbeianus, Pelophylax ridibundus kurtmuelleri, Pelophylax cf. bedriagae, Xenopus laevis, Trachemys scripta, Chamaeleo chamaeleon, Indotyphlops braminus and, probably, Eryx jaculus). More difficult is to ascertain if some well-established species are really autochthonous or if their presence is due to ancient man-mediated introductions (the so-called "parautochthonous" species cf. VV.AA., 2007). Even if biogeographic and genetic data strongly support the introduction of some species in ancient times (i.e. Testudo marginata, T. graeca and Emys orbicularis in Sardinia), for other (Chalcides chalcides, C. ocellatus, Podarcis siculus, Natrix maura and Hemorrhois hippocrepis in Sardinia, Podarcis filfolensis on Linosa and Lampione, Mediodactylus kotschyi in Apulia and Basilicata) the last word has yet to be said.

Some species, native or putatively native in some regions of Italy, are present as alien species in other areas: it is the case of Tarentola mauritanica, Hemidactylus turcicus and Mediodactylus kotschyi in northern Italy, Podarcis siculus siculus near the Garda Lake, Proteus anguinus in Veneto, Speleomantes strinatii in Venezia Giulia, Speleomantes ambrosii and S. italicus in Siena province (Tuscany), Bufo bufo in Sardinia etc., and very likely of Algyroides nigropunctatus in Apulia. As for Hyla meridionalis, which is believed to be introduced in historical times in Europe, although with no definitive evidence (Recuero et al., 2007), its presence in Italy is probably due to its subsequent spontaneous expansion from southern France. 
Comparing the new checklist with those of Lanza in Amori et al. (1993) and Razzetti et al. (2006), Vipera walser has been described, Salamandrina perspicillata, Speleomantes sarrabusensis, Zootoca carniolica, Malpolon insignitus and Natrix helvetica, have been raised to species rank, Bombina pachypus, Pelophylax bergeri and P. kurtmuelleri have been downgraded to subspecies.

Besides some species listed dubitatively by Lanza in Amori et al. (1993) have never been recorded in Italy (i.e. Rana arvalis, Pelophylax perezi, Pseudopus apodus, Lacerta trilineata, Platyceps najadum), some other, reported by Lanza as belonging to the Italian fauna, are here excluded: Mauremys caspica and M. leprosa since naturalized populations are unknown, Hierophis gemonensis (reported in Italy on the basis of misidentified juveniles of $H$. viridiflavus), and Zamenis scalaris (reported once in Italy close to the French border, but never confirmed again).

To better understand the origin of dubiously native species (cryptogenic species) and the taxonomic status of some Italian populations further investigations are needed, especially for the following taxa:

- the specific allocation of Speleomantes ambrosii bianchii alternatively regarded as a subspecies of $S$. italicus or of S. ambrosii by different authors;

- the taxonomic status of the Italian populations of Proteus anguinus;

- the infraspecific taxonomy of Rana temporaria in Italy;

- the taxonomy of Tarentola from Lampedusa Island and the nearby Isola dei Conigli;

- the actual specific distinction between Lacerta viridis and L. bilineata, and the status and taxonomy of the Adriatic lineage of the Lacerta viridis complex;

- the infraspecific taxonomy of Podarcis muralis;

- the infraspecific taxonomy of Podarcis siculus;

- the infraspecific taxonomy of Zootoca vivipara in Italy;

- the relationships of Psammodromus algirus from Isola dei Conigli;

- the origin of Sicilian Eryx jaculus;

- the specific allocation of the Macroprotodon population of Lampedusa;

- the infraspecific taxonomy of Coronella austriaca;

- the taxonomic status of Natrix helvetica and N. natrix, due to the wide hybridization area observed in northeastern Italy;

- the taxonomic status of Aesculapian snakes (Zamenis) from Apulia.

\section{CHECKLIST}

\section{Class Amphibia Linnaeus 1758}

\section{Order Urodela Duméril 1805}

Family Salamandridae Goldfuss 1820

Genus Euproctus Gené 1839
Euproctus platycephalus (Gravenhorst 1829)

Genus Ichthyosaura Sonnini \& Latreille 1801

Ichthyosaura alpestris (Laurenti 1768)

Ichthyosaura alpestris alpestris (Laurenti 1768)

Ichthyosaura alpestris apuana (Bonaparte 1839)

Ichthyosaura alpestris inexpectata (Dubois \& Breuil 1983) ${ }^{1}$

Genus Lissotriton Bell 1839

Lissotriton italicus (Peracca 1898)

Lissotriton vulgaris (Linnaeus 1758)

Lissotriton vulgaris vulgaris (Linnaeus 1758)

Lissotriton vulgaris meridionalis (Boulenger 1882) ${ }^{2}$

Genus Salamandra Garsault $1764^{3}$

Salamandra atra (Laurenti 1768)

Salamandra atra atra (Laurenti 1768)

Salamandra atra aurorae (Trevisan 1982)

Salamandra atra pasubiensis (Bonato \& Steinfartz 2005)

Salamandra lanzai (Nascetti, Andreone, Capula \& Bullini 1988)

Salamandra salamandra (Linnaeus 1758)

Salamandra salamandra salamandra (Linnaeus 1758)

Salamandra salamandra gigliolii (Eiselt \& Lanza $1956)^{4}$

Genus Salamandrina Fitzinger 1826

Salamandrina perspicillata (Savi 1821)

Salamandrina terdigitata (Bonnaterre 1789)

Genus Triturus Rafinesque 1815

Triturus carnifex (Laurenti 1768) ${ }^{6}$

\section{Family Plethodontidae Gray 1850}

Genus Speleomantes Dubois $1984^{7}$

Speleomantes ambrosii (Lanza 1955)

Speleomantes ambrosii ambrosii (Lanza 1955)

Speleomantes ambrosii bianchii Lanza, Cimmaruta,

Forti, Bullini \& Nascetti $2005^{8}$

Speleomantes flavus (Stefani 1969)

Speleomantes genei (Temminck \& Schlegel 1838) ${ }^{9}$

Speleomantes imperialis (Stefani 1969)

Speleomantes italicus (Dunn 1923) ${ }^{10}$

Speleomantes sarrabusensis Lanza, Leo, Forti, Cimmaruta, Caputo \& Nascetti $2001^{11}$

Speleomantes strinatii (Aellen 1958)

Speleomantes supramontis (Lanza, Nascetti \& Bullini 1986)

Family Proteidae Gray 1825

Genus Proteus Laurenti 1768

Proteus anguinus Laurenti $1768^{12}$

\section{Order Anura Duméril 1805}

Family Alytidae Fitzinger 1843

Genus Discoglossus Otth 1837

Discoglossus pictus Otth $1837^{13}$

Discoglossus sardus Tschudi in Otth 1837

Family Bombinatoridae Gray 1825

Genus Bombina Oken 1816

Bombina variegata (Linnaeus 1758) 
Bombina variegata variegata (Linnaeus 1758)

Bombina variegata pachypus (Bonaparte 1838) ${ }^{14}$

Family Pipidae Gray 1825

Genus Xenopus Wagler 1827

Xenopus laevis (Daudin 1802) ${ }^{15}$

Family Pelobatidae Bonaparte 1850

Genus Pelobates Wagler 1830

Pelobates fuscus (Laurenti 1768) ${ }^{16}$

Family Pelodytidae Bonaparte 1850

Genus Pelodytes Bonaparte 1838

Pelodytes punctatus (Daudin 1802)

Family Bufonidae Gray 1825

Genus Bufo Garsault $1764^{17}$

Bufo bufo (Linnaeus 1758) ${ }^{18}$

Bufo spinosus (Daudin 1803) ${ }^{19}$

Genus Bufotes Rafinesque 1815

Bufotes boulengeri (Lataste 1879)

Bufotes boulengeri boulengeri (Lataste 1879)

Bufotes boulengeri siculus (Stöck, Sicilia, Belfiore,

Buckley, Lo Brutto, Lo Valvo \& Arculeo 2008) ${ }^{20}$

Bufotes viridis (Laurenti 1768)

Bufotes viridis viridis (Laurenti 1768)

Bufotes viridis balearicus (Boettger 1880) ${ }^{21}$

Family Hylidae Rafinesque 1815

Genus Hyla Laurenti 1768

Hyla arborea (Linnaeus 1758) 22

Hyla intermedia Boulenger 1882

Hyla intermedia intermedia Boulenger 1882

Hyla intermedia perrini Dufresnes, Mazepa, Rodrigues, Brelsford, Litvinchuk, Sermier, Lavanchy, Betto-Colliard, Blaser, Borzée, Cavoto, Fabre, Ghali, Grossen, Horn, Leuenberger, Phillips, Saunders, Savary, Maddalena, Stöck, Dubey, Canestrelli \& Jeffries $2018^{23}$

Hyla meridionalis Boettger 1874

Hyla sarda (de Betta 1857)

Family Ranidae Batsch 1796

Genus Pelophylax Fitzinger $1843^{24}$

Pelophylax cf. bedriagae (Camerano 1882) ${ }^{25}$

Pelophylax lessonae (Camerano 1882)

Pelophylax lessonae lessonae (Camerano 1882)

Pelophylax lessonae bergeri (Günther 1986) ${ }^{26}$

Pelophylax kl. esculentus (Linnaeus 1758)

Pelophylax ridibundus (Pallas 1771)

Pelophylax ridibundus ridibundus (Pallas 1771)

Pelophylax ridibundus kurtmuelleri (Gayda 1940) ${ }^{27}$

Genus Lithobates Fitzinger 1843

Lithobates catesbeianus (Shaw 1802) ${ }^{28}$

Genus Rana Linnaeus 1758

Rana dalmatina Fitzinger in Bonaparte 1838

Rana italica Dubois 1987

Rana latastei Boulenger 1879

Rana temporaria Linnaeus $1758^{29}$

\section{Class Reptilia Laurenti 1768}

\section{Order Testudines Linnaeus 1758}

Family Cheloniidae Oppel 1811

Genus Caretta Rafinesque-Schmaltz 1814

Caretta caretta (Linnaeus 1758)

Genus Chelonia Brongniart 1800

Chelonia mydas (Linnaeus 1758)

Chelonia mydas mydas (Linnaeus 1758)

Genus Eretmochelys Fitzinger 1843

Eretmochelys imbricata (Linnaeus 1766) ${ }^{30}$

Genus Lepidochelys Fitzinger 1843

Lepidochelys kempii (Garman 1880) ${ }^{31}$

Family Dermochelyidae Fitzinger 1843

Genus Dermochelys de Blainville 1816

Dermochelys coriacea (Vandelli 1761)

Family Testudinidae Batsch 1788

Genus Testudo Linnaeus 1758

Testudo graeca Linnaeus 1758

Testudo graeca nabeulensis (Highfield 1990) ${ }^{32}$

Testudo hermanni Gmelin $1789^{33}$

Testudo hermanni hermanni Gmelin 1789

Testudo hermanni boettgeri Mojsisovics 1889

Testudo marginata Schoepff 1792

Family Emydidae Rafinesque 1815

Genus Emys Duméril 1805

Emys orbicularis (Linnaeus 1758)

Emys orbicularis galloitalica Fritz $1995^{35}$

Emys orbicularis hellenica (Valenciennes 1832)

Emys orbicularis trinacris Fritz, Fattizzo, Guicking,

Tripepi, Pennisi, Lenk, Joger \& Wink 2005

Genus Trachemys Agassiz 1857

Trachemys scripta (Thunberg in Schoepff 1792) ) $^{36}$

Trachemys scripta elegans (Wied 1838)

Trachemys scripta scripta (Thunberg in Schoepff 1792)

\section{Order Squamata Oppel 1811}

Family Chamaeleonidae Rafinesque 1815

Genus Chamaeleo Laurenti 1768

Chamaeleo chamaeleon (Linnaeus 1758) ${ }^{37}$

Family Sphaerodactylidae Underwood 1954

Genus Euleptes Fitzinger 1843

Euleptes europaea (Gené 1839)

Family Gekkonidae Oppel 1811

Genus Hemidactylus Oken 1817

Hemidactylus turcicus (Linnaeus 1758)

Genus Mediodactylus Szczerbak \& Golubev 1977

Mediodactylus kotschyi (Steindachner 1870)

Mediodactylus kotschyi kotschyi (Steindachner $1870)^{39}$ 
Family Phyllodactylidae Gamble, Bauer, Greenbaum \& Jackman 2008

Genus Tarentola Gray 1825

Tarentola mauritanica (Linnaeus 1758) 40 $^{4}$

Family Lacertidae Batsch 1788

Genus Algyroides Bibron \& Bory de Saint-Vincent 1833

Algyroides fitzingeri (Wiegmann 1834)

Algyroides nigropunctatus (Duméril \& Bibron 1839)

Algyroides nigropunctatus nigropunctatus (Duméril \& Bibron 1839) ${ }^{41}$

Genus Archaeolacerta Mertens 1921

Archaeolacerta bedriagae (Camerano 1885) ${ }^{42}$

Genus Iberolacerta Arribas 1997

Iberolacerta horvathi (Méhely 1904)

Genus Lacerta Linnaeus 1758

Lacerta agilis Linnaeus 1758

Lacerta agilis agilis Linnaeus $1758^{43}$

Lacerta bilineata Daudin $1802^{44}$

Lacerta bilineata bilineata Daudin 1802

Lacerta bilineata chloronota Rafinesque 1810

Lacerta sp. $^{45}$

Genus Podarcis Wagler 1830

Podarcis filfolensis (Bedriaga 1876) ${ }^{46}$

Podarcis melisellensis (Braun 1877)

Podarcis melisellensis fiumanus (Werner 1891) ${ }^{47}$

Podarcis muralis (Laurenti 1768) ${ }^{48}$

Podarcis raffonei (Mertens 1952) ${ }^{49}$

Podarcis siculus (Rafinesque-Schmaltz 1810)

Podarcis tiliguerta (Gmelin 1789) ${ }^{51}$

Podarcis waglerianus Gistel $1868^{52}$

Podarcis waglerianus waglerianus Gistel 1868

Podarcis waglerianus marettimensis (Klemmer 1956)

Genus Psammodromus Fitzinger 1826

Psammodromus algirus (Linnaeus 1758) ${ }^{53}$

Genus Timon Tschudi 1836

Timon lepidus (Daudin 1802)

Timon lepidus lepidus (Daudin 1802)

Genus Zootoca Wagler 1830

Zootoca carniolica Mayer, Böhme, Tiedemann \& Bischoff $2000^{54}$

Zootoca vivipara (Lichtenstein 1823$)^{55}$

Family Scincidae Oppel 1811

Genus Chalcides Laurenti 1768

Chalcides chalcides (Linnaeus 1758)

Chalcides chalcides chalcides (Linnaeus 1758)

Chalcides chalcides vittatus (Leuckart 1828) ${ }^{56}$

Chalcides ocellatus (Forskål 1775)

Chalcides ocellatus linosae Boulenger 1920

Chalcides ocellatus tiligugu (Gmelin 1789)

Chalcides ocellatus zavattarii Lanza 1954

Chalcides striatus (Cuvier 1829)

Family Anguidae Gray 1825

Genus Anguis Linnaeus $1758^{57}$

Anguis veronensis Pollini $1818^{58}$

Family Typhlopidae Merrem 1820

Genus Indotyphlops Hedges, Marion, Lipp, Marin \& Vidal 2014
Indotyphlops braminus (Daudin 1803) $)^{59}$

Family Erycidae Bonaparte 1840

Genus Eryx Daudin 1803

Eryx jaculus (Linnaeus 1758)

Family Psammophiidae Boie 1827

Genus Malpolon Fitzinger 1826

Malpolon insignitus (Geoffroy Saint-Hilaire 1827) ${ }^{61}$

Malpolon insignitus insignitus (Geoffroy Saint-Hilaire 1827)

Malpolon monspessulanus (Hermann 1804) ${ }^{62}$

Malpolon monspessulanus monspessulanus (Hermann 1804)

Family Natricidae Bonaparte 1840

Genus Natrix Laurenti 1768

Natrix helvetica (Lacépède 1789) ${ }^{63}$

Natrix helvetica cetti Gené 1839

Natrix helvetica sicula (Cuvier 1829) ${ }^{64}$

Natrix maura (Linnaeus 1758)

Natrix natrix (Linnaeus 1758)

Natrix natrix persa (Pallas 1814) ${ }^{65}$

Natrix tessellata (Laurenti 1768)

Family Colubridae Oppel 1811

Genus Coronella Laurenti 1768

Coronella austriaca Laurenti 1768

Coronella austriaca austriaca Laurenti $1768^{66}$

Coronella girondica (Daudin 1803)

Genus Elaphe Fitzinger 1833

Elaphe quatuorlineata (Bonnaterre 1790) ${ }^{67}$

Elaphe quatuorlineata quatuorlineata (Bonnaterre 1790)

Genus Hemorrhois Boie 1826

Hemorrhois hippocrepis (Linnaeus 1758) ${ }^{68}$

Genus Hierophis Fitzinger in Bonaparte 1834

Hierophis viridiflavus (Lacépède 1789) ${ }^{69}$

Hierophis viridiflavus viridiflavus (Lacépède 1789)

Hierophis viridiflavus carbonarius (Bonaparte 1833)

Genus Macroprotodon Guichenot 1850

Macroprotodon cf. cucullatus (Geoffroy Saint-Hilaire $1827)^{70}$

Genus Telescopus Wagler 1830

Telescopus fallax (Fleischmann 1831)

Telescopus fallax fallax (Fleischmann 1831)

Genus Zamenis Wagler $1830^{71}$

Zamenis lineatus (Camerano 1891) ${ }^{72}$

Zamenis longissimus (Laurenti 1768)

Zamenis situla (Linnaeus 1758)

Family Viperidae Oppel 1811

Genus Vipera Garsault 1764

Vipera ammodytes (Linnaeus 1758) ${ }^{73}$

Vipera ammodytes ammodytes (Linnaeus 1758)

Vipera aspis (Linnaeus 1758) ${ }^{74}$

Vipera aspis aspis (Linnaeus 1758)

Vipera aspis francisciredi (Laurenti 1768)

Vipera aspis hugyi (Schinz 1834)

Vipera berus (Linnaeus 1758)

Vipera berus marasso (Pollini 1818) $)^{75}$ 
Vipera berus walser Ghielmi, Menegon, Marsden, Laddaga \& Ursenbacher $2016^{76}$

Vipera ursinii (Bonaparte 1835)

Vipera ursinii ursinii (Bonaparte 1835)

\section{NOTES}

${ }^{1}$ Ichthyosaura alpestris inexpectata - The taxonomic status of $I$. a. inexpectata (Dubois \& Breuil 1983) from Calabria is debated: Speybroeck et al., (2010), Sotiropoulos et al. (2007) and Recuero et al. (2014) considered $I$. a. inexpectata as a synonym of $I$. $a$. apuana, while Chiocchio et al. (2017) consider it a valid taxon.

${ }^{2}$ Lissotriton vulgaris meridionalis - The subspecific rank is confirmed by Pabijan et al. $(2015,2017)$.

${ }^{3}$ Salamandra - Dubois \& Bour (2010) proved that the genera Salamandra, Bufo and Vipera created by Garsault (1764) have priority over the genera with the same name created by Laurenti (1768). Therefore, Salamandra Laurenti 1768 and Salamandra Garsault 1764 should be considered different genera and brackets around the author's name and date of description (if before Dubois \& Bour paper) should be used accordingly, see also article 51.3 of the code of nomenclature (ICZN, 1999).

${ }^{4}$ Salamandra salamandra gigliolii - The Apennine populations (usually considered S. s. gigliolii), between the eastern Liguria and Campania, are introgressed, with a geographic discordance exceeding $600 \mathrm{~km}$ between groups identified with mtDNA and nuDNA. "Pure" populations of S. s. salamandra inhabit the Alps and western Liguria, while "pure" S. s. gigliolii are confined to Calabria (Bisconti et al., 2018).

${ }^{5}$ Salamandrina perspicillata - Species status according to Mattoccia et al. (2005) and Romano et al. (2009).

${ }^{6}$ Triturus carnifex - Monotypic if T. macedonicus is recognised at species rank (Arntzen et al., 2007). Recent mtDNA-based phylogeographic study observed a basal split between the Italian and the Balkan populations with a restricted admixture at the contact and an admixture over a broader area at the contact between the northern and southern Italy lineages (Wielstra et al., 2014, 2021).

${ }^{7}$ Speleomantes - American authors support the use of Speleomantes as a subgenus of Hydromantes, while many European authors support the generic rank for Speleomantes. For a summary of the debate, see Frost (2020).

${ }^{8}$ Speleomantes ambrosii bianchii - Taxonomic assessment uncertain. According to the phylogenetic study by Carranza et al. (2008) $S$. a. bianchii would be closer to $S$. italicus than to $S$. ambrosii. On the contrary, S. ambrosii would be closer to $S$. italicus than to $S$. $a$. bianchii in the phylogeny by van der Meijden et al. (2009).

${ }^{9}$ Speleomantes genei - Some authors assigned this species to the genus Atylodes (Vieites et al. 2007), but later they re-assigned it to the genus Speleomantes (Vieites et al. 2011).

${ }^{10}$ Speleomantes italicus - Ruggi (2007) has shown that S. italicus populations introgressed with genes of $S$. ambrosii bianchii occur in Tuscany (Florence, Lucca and Pistoia provinces) and EmiliaRomagna (Modena and Bologna provinces); pure populations of $S$. italicus are present in Emilia-Romagna (Reggio Emilia province), Marche, Umbria, Latium and Abruzzo.

${ }^{11}$ Speleomantes sarrabusensis - Elevated to species rank by Carranza et al. (2008).

${ }^{12}$ Proteus anguinus - The status of the subspecies of Proteus anguinus, including P. a. parkelj Sket \& Arntzen 1994, is still uncertain. Gorički \& Trontelj (2006), Gorički et al. (2017) and Trontelj et al. (2009) found six lineages but refrained from assigning them scientific names.

${ }^{13}$ Discoglossus pictus - Monotypic according to Zangari et al. (2006): "The little genetic differentiation detected among Algerian and Tunisian D. p. auritus with respect to Maltese and Sicilian D. p. pictus suggested a very recent isolation of Sicilian populations and did not support the necessity of a subspecific rank for D. p. auritus". Also, Stöck et al. (2015) recorded very close relationships between Sicilian and North African populations.

${ }^{14}$ Bombina variegata pachypus - The specific rank of Bombina pachypus is not supported by phylogenetic studies (Hofman et al., 2007; Zheng et al., 2009; Fijarczyk et al., 2011), while Hofman et al. (2007) and Fijarczyk et al. (2011) consider it as a subspecies.
${ }^{15}$ Xenopus laevis - Taxonomy of Italian populations according to Lillo et al. (2013).

${ }^{16}$ Pelobates fuscus - The validity of the ssp. insubricus Cornalia 1873 is not supported by phylogenetic studies (Crottini et al., 2007; Litvinchuk et al., 2013) based on allozyme, genome content and mtDNA data.

${ }^{17}$ Bufo - For the brackets around authors names see note 3.

${ }^{18}$ Bufo bufo - Monotypic if $B$. b. verrucosissimus Pallas 1814 is regarded at the species rank (Arntzen et al., 2013). The recently discovered Sardinian population (Cossu et al., 2018) is likely introduced.

${ }^{19}$ Bufo spinosus - The Western Ligurian populations of the genus Bufo, from the French border up to Calice Ligure, have been recently assigned to this species based on genetic evidence (Recuero et al., 2012; Arntzen et al., 2020).

${ }^{20}$ Bufotes boulengeri siculus - Subspecific status according to Speybroeck et al. (2020) and Dufresnes et al. (2019).

${ }^{21}$ Bufotes viridis balearicus - We follow Speybroeck et al. (2020) to consider B. balearicus as a subspecies of $B$. viridis, due to the wide hybrid zone in north-east Italy (Dufresnes et al., 2014).

${ }^{22}$ Hyla arborea - Verardi et al. (2009) found neither $\mathrm{F}_{1}$ and $\mathrm{F}_{2}$ hybrids nor backcrosses between H. intermedia and H. arborea in northeast Italy.

${ }^{23}$ Hyla intermedia perrini - Subspecific status of Hyla perrini according to Speybroeck et al. (2020).

${ }^{24}$ Pelophylax - A single genetically identified specimen of Pelophylax shqipericus (Hotz, Uzzell, Günther, Tunner \& Heppich 1987) was recorded in Umbria in syntopy with $P$. ridibundus (Domeneghetti et al. 2013). At the moment it is not known if there is a viable population, or if it is an ephemeral introduction that will not lead to a naturalization of the species.

${ }^{25}$ Pelophylax cf. bedriagae - Introduced in Sardinia, Tuscany and possibly in Emilia Romagna (Bellati et al., 2019) with at least two distinct lineages: " $P$. cf. bedriagae sensu stricto" (native to Anatolia, Greece, Russia) in Northern Sardinia and Tuscany and " $P$. cf. bedriagae Cilician West" (native to SE Anatolia) in Southern Sardinia.

${ }^{26}$ Pelophylax kl. esculentus - Subspecific status according to Canestrelli \& Nascetti (2008). The hemiclonal hybrid of P. bergeri is called Pelophylax kl. hispanicus (Bonaparte 1839).

${ }_{27}^{27}$ Pelophylax ridibundus kurtmuelleri - Not recognised at the species rank by Speybroeck et al. (2010, 2020).

${ }^{28}$ Lithobates catesbeianus - Included in the genus Lithobates according to Amphibian Species of the World 6.0. Yuan et al. (2016) consider catesbeiana belonging to Rana (Aquarana), while Dubois (2007) considers Aquarana as a synonym of Lithobates.

${ }^{29}$ Rana temporaria - "The European common frog contains deep mitochondrial lineages, some of which are given the rank of subspecies (Veith et al., 2002, 2003, 2012; Palo et al., 2004; Teacher et al., 2009), but the exact geographic distribution of these lineages is unknown, as a range-wide comprehensive phylogeographic study for this species is missing so far" (Vences et al., 2013). The phylogenetic study by Stefani et al. (2012) does not support any taxonomic distinction at the subspecific level for R. temporaria in Italy.

${ }^{30}$ Eretmochelys imbricata - A very rare vagrant species in the Mediterranean; a single individual has been ascertained from Italian waters, close to the southern Sicilian coast (http://www.seaturtle.org/ $\mathrm{mtn} / \operatorname{archives} / \mathrm{mtn} 54 / \mathrm{mtn} 54 \mathrm{p} 12 . \mathrm{shtml})$. The subspecific status of this vagrant individual is unknown.

${ }^{31}$ Lepidochelys kempii - A very rare vagrant species in the Mediterranean; it is known as a single individual from Italian waters, captured near Messina (Insacco \& Spadola, 2010).

${ }^{32}$ Testudo graeca nabeulensis - Fritz et al. (2009) assigned specimens from Sardinia to "subspecies uncertain", although all examined Sardinian specimens belong to the Tunisian clade (ssp. T. g. nabeulensis), according the same authors.

${ }^{33}$ Testudo hermanni - In Italy T. h. hermanni is widespread in the peninsula and islands, except in two northern Adriatic populations (Bosco Nordio and Bosco Mesola), where T. h. boettgeri prevails (Perez et al., 2014; Biello et al., 2021).

${ }^{34}$ Emys orbicularis - The lack of genetic differentiation of pond turtles from Sardinia (and Corsica) supports the view that the subspecies described from these islands (respectively E. o. capolongoi 
Fritz 1995 and E. o. lanzai Fritz 1995) are not valid (Pedall et al., 2010).

${ }^{35}$ Emys orbicularis galloitalica - E. orbicularis ingauna Jesu, Piombo, Salvidio, Lamagni, Ortale \& Genta 2004 is a taxon of uncertain validity (Manfredi et al., 2013) occurring in western Liguria, within the range of $E$. o. galloitalica.

${ }^{36}$ Trachemys scripta - Several terrapin species and subspecies are distributed in natural environments in Italy but currently there is proof of naturalization for two subspecies only (Ficetola et al., 2003; Ferri \& Soccini, 2010; Crescente et al., 2014).

${ }^{37}$ Chamaeleo chamaeleon - Populations from Apulia show genetic affinities both with the North African populations (C. c. chamaeleon) and with populations of two areas in the Middle East (C. c. recticrista Boettger 1980, and C. c. musae Steindachner 1901) (Basso et al., 2019). Specimens from Calabria are genetically similar to Tunisian ones (Andreone et al., 2016). Therefore we refrain from assessing the subspecific status of the introduced Italian populations.

${ }^{38}$ Hemidactylus turcicus - Monotypic, since H. t. spinalis Buchholz 1954 is a synonym (Šmíd et al., 2015) and other subspecies (e.g. H. t. lavadeserticus Moravec \& Böhme 1997) have been raised to the species rank (Moravec et al., 2011).

${ }^{39}$ Mediodactylus kotschyi kotschyi - Italian populations have been attributed to $M$. $k$. bibroni (Beutler \& Gruber 1977), recently put in synonymy with the nominate subspecies (Kotsakiozi et al., 2018).

${ }^{40}$ Tarentola mauritanica - The taxonomy of the T. mauritanica complex is debated. Harris et al. (2009) found that specimens from Lampedusa and the adjacent Conigli islet belong to two clades, one occurring on Lampedusa and Conigli islet, related to Libyan specimens [where T. fascicularis (Daudin 1802) and T. deserti Lataste 1891 occur] and the other representing "a further subclade, distinct from all other known mtDNA lineages", found only in Conigli island. Conversely Stöck et al. (2016) found that Lampedusa specimens are closely related to Cap Bon specimens, where T. mauritanica occurs (Tlili et al., 2012).

${ }^{41}$ Algyroides nigropunctatus nigropunctatus - The population of Venezia Giulia belongs to the nominal subspecies, as well as the Apulian introduced populations (Carlino \& Pauwels, 2016).

${ }^{42}$ Archaeolacerta bedriagae - The validity of the ssp. A. b. sardoa (Peracca 1903), A. b. paessleri (Mertens 1927), and A. b. ferrerae (Stemmler 1962) is not supported by genetic (Salvi et al., 2009, 2010) nor by morphological data (Salvi et al., 2008).

${ }^{43}$ Lacerta agilis agilis - According to morphology (Bischoff, 1988), populations from western Alps are assigned to L. a. agilis, while those of eastern Alps to L. a. argus (Laurenti 1768). The cytochrome-b trees did not recover the subspecies $L$. a. agilis and $L$. a. argus as separate evolutionary lineages (Kalyabina et al., 2001; Andres et al., 2014).

${ }^{44}$ Lacerta bilineata - The study of Marzhan et al. (2016) "could not answer whether L. bilineata and L. viridis represent distinct species without extensive gene flow". Infraspecific taxonomy according to Marzhan et al. (2016). The same authors support the validity of two subspecies only: L. b. bilineata and L. b. chloronota.

${ }^{45}$ Lacerta sp. - Based on genetic evidence, Marzhan et al. (2016) assigned three specimens from Pordenone and Udine provinces to the 'Adriatic' (or 'Western Balkan') lineage. Joss et al. (2021) included in this lineage also an enigmatic specimen from Calambrone (Pisa, Tuscany). According to Jauss et al. (2021) "the lineages [of the $L$. viridis complex] have reached the level of distinct taxa, but to determine whether they have become fully independent lineages on the species level requires further research". In both the mentioned studies the Adriatic clade seems closer to $L$. bilineata than to $L$. viridis. Therefore $L$. viridis s.s. is not a member of the Italian fauna, and at present the status of Italian populations formerly assigned to $L$. viridis is uncertain. The possible available name for the Adriatic lineage are L. v. istriensis Werner 1897 or L. v. intermedia Méhelÿ 1905 (Marzhan et al., 2016).

46 Podarcis filfolensis - Capula (1994a), Salvi et al. (2014) and Rodriguez et al. (2014) suggest that $P$. filfolensis colonized the Pelagian islands from the Maltese archipelago in historical times, therefore the Pelagian ssp. P. f. laurentiimuelleri (Fejérváry 1924) is not valid.
${ }^{47}$ Podarcis melisellensis fiumanus - The subspecies fiumanus is supported by mtDNA (Podnar et al., 2004), electrophoretic data (Gorman et al., 1975), as well as with morphological analysis (Thorpe, 1980).

${ }^{48}$ Podarcis muralis - The observed phylogeographic structure of $P$. muralis does not match the current subspecific division of this species in Italy (Giovannotti et al., 2010; Salvi et al., 2013). Pending a comprehensive revision of the status of the Italian populations, at the moment we refrain from adopting any subspecies.

${ }^{49}$ Podarcis raffonei - Taxonomic status according to Capula (1994b). The genetic distance found between $P$. raffonei and $P$. waglerianus is relatively small for Podarcis species (Podnar \& Mayer, 2005; Senczuk et al., 2019). Depending on the markers used the divergence between raffonei and waglerianus is not that different than for other sister species of Podarcis (e.g. lilfordi and pityusensis, tauricus and ionicus) (Salvi et al., 2021). The validity of the subspecies raffonei (Mertens 1952), alvearioi (Mertens 1955), cucchiarai Di Palma 1980 and antoninoi (Mertens 1955) is not supported by genetic data (Capula, 2004).

${ }^{50}$ Podarcis siculus - This species shows many mitochondrial lineages both in the continent and in some large islands (Podnar et al., 2005; Silva-Rocha et al., 2012; Senczuk et al., 2018) whose ranges and extent of hybridization are not known (D. Salvi in litt.). One of the main branches includes specimens from Sicily, Sardinia and part of Calabria, the other branch the remnant Italian populations (both with campestris or siculus phenotypes). According to Podnar et al. (2005) P. s. cettii (Cara 1872) from Sardinia was introduced in historical times and originated from Sicily, and it is therefore a synonym of $P$. s. siculus. Recently the populations of $P$. siculus from western Pontine Islands have been raised to species rank Podarcis latastei (Bedriaga 1879) by Senczuk et al. (2019). This proposal has been rejected by Speybroeck et al. (2020) but defended by Castiglia et al. (2021). Pending a thorough revision of the species, we adopt the more conservative opinion by Speybroeck et al. (2020).

${ }^{51}$ Podarcis tiliguerta - The identity of ssp. ranzii (Lanza 1967) from Molarotto Island doesn't seem supported by mtDNA (Vasconcelos et al., 2006).

${ }^{52}$ Podarcis waglerianus - The subspecies $P$. w. marettimensis is supported by having only private haplotypes (Senczuk et al., 2018).

${ }^{53}$ Psammodromus algirus - According to Carretero et al. (2009) a single individual from Conigli Islet near Lampedusa grouped with those from Morocco (ssp. algirus) and not with the closer Tunisian ones, suggesting a recent, human-mediated, colonization, although a transport between Morocco and the uninhabited Conigli islet seems unlikely. Moreover, the taxonomic value of the two other North African subspecies, P. a. nollii (Fischer 1887) and P. a. doriae (Bedriaga 1866) has not yet been tested by genetic studies.

${ }^{54}$ Zootoca carniolica - Species rank after Cornetti et al. $(2015 \mathrm{a}$, 2015b).

${ }^{55}$ Zootoca vivipara - Authorship according to Schmidtler \& Böhme (2011). The phylogeographic study by Horreo et al. (2018) seems not to support the current infraspecific taxonomy. The authors identified six clades of Zootoca (one of which is currently Z. carniolica); the Italian populations belong to the clade E, while the type locality is inhabited by the clade C. Waiting for further studies resolving the complicated relationships of the subspecies we do not adopt any subspecific name for the Italian populations.

${ }^{56}$ Chalcides chalcides vittatus - The Sardinian populations would have colonized this island in historical times, by passive transportation, starting from Tunisian or Libyan populations, as is suggested by the morphological and genetic resemblance between these populations (Caputo, 1993).

${ }^{57}$ Anguis - A hybrid A. fragilis x A. cinerea (=veronensis) is reported in Friuli - Venezia Giulia by Gvoždík et al. (2013). The occurrence of $A$. fragilis is expected in north-east Italy, but has yet to be demonstrated.

${ }^{58}$ Anguis veronensis - Italian Anguis have been recognized as a full species under the name Anguis veronensis by Gvoždík et al. (2013). An early version "in press" of the same paper listed the species as A. cinerea Risso 1826.

59 Indotyphlops braminus - Recently discovered on Ischia island (Naples province) and in Sicily, near Paceco (Trapani province) (Faraone et al., 2019, Paolino et al., 2019). 
${ }^{60}$ Eryx jaculus - The morphological characters of the Sicilian population resemble those of African populations (ssp. jaculus), but molecular studies are needed to confirm this hypothesis (Faraone et al., 2019). According to Tokar (1991) the species is monotypic.

${ }^{61}$ Malpolon insignitus - Species rank after Carranza et al. (2006). The date of publication of the description is listed here according to Opinion 1416 (ICZN, 1987).

${ }^{62}$ Malpolon monspessulanus - Besides the nominate subspecies, $M$. m. saharatlanticus Geniez, Cluchier \& de Haan 2006 has been described on morphological basis, but its validity has not yet been tested by genetic data.

${ }^{63}$ Natrix helvetica - Species rank and infraspecific taxonomy according to Schultze et al. (2020). Moreover, the paper does not report any Natrix helvetica helvetica in Italy albeit at least one sample (MSNVE 684) from Taggia (IM) shows Natrix helvetica helvetica introgression (cf. supplementary materials).

${ }^{64}$ Natrix helvetica sicula - Including calabra Vanni \& Lanza, in Lanza 1983 and lanzai Kramer 1970. See Fritz \& Schmidtler (2020) for a complete discussion about scientific names erected for $N$. natrix and $N$. helvetica.

${ }^{65}$ Natrix natrix persa - Italian populations are tentatively attributed to N. n. persa according to Kindler et al. (2017). Schultze et al. (2020) found in northeastern Italy a hybrid zone 70-90 km wide between $N$. natrix and $N$. helvetica, already observed by Thorpe (1979) based on morphology. The westernmost records come from close to the Po estuary and Ferrara (Emilia-Romagna).

${ }^{66}$ Coronella austriaca austriaca - "The current taxonomy of C. austriaca [...] requires a thorough revision" (Jablonski et al., 2019). The subspecies described from Sicily, C. a. fitzingeri (Bonaparte 1840), is not generally accepted, but the phylogenetic studies by Santos et al. (2008) and Jablonski et al. (2019) place the Sicilian specimens in a separate mtDNA clade. Its taxonomic status can only be clarified by analyzing enough material from all over the Italian range.

${ }^{67}$ Elaphe quatuorlineata - Coluber quatuor-lineatus Lacépède 1789 was declared nomen conservandum in Opinion 490 (ICZN, 1957) but later the species was not explicitly excluded by effects of Opinion 1463 (ICZN, 1987) that ruled Lacépède, 1789 as a non-binomial work.

${ }^{68}$ Hemorrhois hippocrepis - Probably introduced in Sardinia and possibly also in Pantelleria (Luiselli et al., 2010 [2011]). According to Luiselli et al. (2010) the species is monotypic. A recent study shows that specimens of Pantelleria (ssp. nigrescens Cattaneo 1985) and Sardinia belong to the "eastern mitochondrial clade", and it supports the hypothesis of an ancient human-mediated introduction in Sardinia, and a recent colonization (human-mediated or through a recent passive dispersion mechanisms) in Pantelleria (Faraone et al., 2020).

${ }^{69}$ Hierophis viridiflavus - Mezzasalma et al. (2015) raised H. carbonarius to the species rank. Speybroeck et al. (2020) recommend maintaining Hierophis viridiflavus carbonarius as a subspecies for the time being, since the amount of divergence in mtDNA between $H$. v. carbonarius and $H$. v. viridiflavus is much lower than between the closely related H. gemonensis and H. viridiflavus (Rato et al., 2009).

${ }^{70}$ Macroprotodon cucullatus - The specific assignment of the Italian population (Lampedusa island) of Macroprotodon, usually referred to M. cucullatus, is still uncertain according to Faraone et al. (2020).

${ }^{71}$ Zamenis - A specimen of Zamenis scalaris (Schinz 1822) was reported in Italy close to France (Calmonte \& Ferri, 1987), but despite intensive research it was not possible to confirm the presence of the species in Italy, which is therefore excluded from the Italian fauna.

${ }^{72}$ Zamenis lineatus - There is "pervasive introgressive hybridization with Z. longissimus in the eastern contact zone.” (Salvi et al., 2017, 2018); therefore the status of Apulian populations remains to be evaluated.

${ }^{73}$ Vipera ammodytes - Intraspecific taxonomy follows Ursenbacher et al. (2008), according to which V.a. ruffoi Bruno 1968 is a synonym of the nominate subspecies.

${ }^{74}$ Vipera aspis - Intraspecific taxonomy according to Ursenbacher et al. (2006) and Barbanera et al. (2009). For the brackets around author names see note 3 .
${ }^{75}$ Vipera berus marasso - According to Schmidtler (2019) the available name for the Alpine (and Italian) populations is Vipera berus marasso (Pollini, 1818), with type locality Legnago, province of Verona, in the Po plain.

${ }^{76}$ Vipera berus walser - Species status debated. Previously considered an isolated population of $V$. berus (Capra, 1954; Sindaco et al., 2006), according to the phylogeny by Ghielmi et al. (2016) $\mathrm{V}$. walser seems surprisingly related to the Caucasian species of the V. ursinii complex. Speybroeck et al. (2020) consider premature the acceptance of the new species due to the possible existence of cito-nuclear discordance and tentatively regard it as a subspecies of Vipera berus. Freitas et al. (2020) consider $V$. walser a valid species (Boettger 1889). Doniol-Valcroze et al. (2021) confirm the cito-nuclear discordance suspected by Speybroeck et al. (2020). Therefore, following these authors, we consider $V$. walser as a subspecies of $V$. berus.

\section{Acknowledgments}

Thanks to the Scientific Committee of the Fauna d'Italia, and particularly to Marco A. Bologna, Fabio Stoch and Fabio Cianferoni, who invited us to update the Italian fauna checklist for amphibians and reptiles.

The authors are grateful to Matteo Di Nicola, Francesco Ficetola and Luciano Di Tizio for the careful reading of the draft and their useful suggestions.

Special thanks to the reviewers, Daniele Salvi and Lucio Bonato, whose comments and suggestions greatly improved the paper.

\section{REFERENCES}

Amori G., Angelici F., Frugis S., Gandolfi G., Groppali R., Lanza B., Relini G. \& Vicini G., 1993 - 110: Vertebrata. In: Checklist delle specie della fauna italiana. Minelli A., Ruffo S. \& La Posta S. (eds.). Calderini, Bologna.

Andreone F., Angelici F. M., Carlino P., Tripepi S. \& Crottini A., 2016 The common chameleon Chamaeleo chamaeleon in southern Italy: evidence for allochthony of populations in Apulia and Calabria (Reptilia: Squamata: Chamaeleonidae). Italian Journal of Zoology, 83 (3): 372-381.

Andres C., Franke F., Bleidorn C., Bernhard D. \& Schlegel M., 2014 Phylogenetic analysis of the Lacerta agilis subspecies complex. Systematics and Biodiversity, 12 (1): 43-54.

Arntzen J. W., Themudo G. E. \& Wielstra B., 2007 - The phylogeny of crested newts (Triturus cristatus superspecies): nuclear and mitochondrial genetic characters suggest a hard polytomy, in line with the paleogeography of the centre of origin. Contributions to Zoology, 76 (4): 261-278.

Arntzen J. W., Recuero E., Canestrelli D. \& Martínez-Solano I., 2013 How complex is the Bufo bufo species group? Molecular Phylogenetics and Evolution, 69: 1203-1208.

Arntzen J. W., Recuero E., Canestrelli D. \& Martínez-Solano I., 2020 Environmental correlates of the European common toad hybrid zone. Contributions to Zoology, 89 (3): 270-281.

Barbanera F., Zuffi M. A., Guerrini M., Gentilli A., Tofanelli S., Fasola M. \& Dini F., 2009 - Molecular phylogeography of the asp viper Vipera aspis (Linnaeus, 1758) in Italy: evidence for introgressive hybridization and mitochondrial DNA capture. Molecular Phylogenetics and Evolution, 52 (1): 103-114.

Basso R., Vannuccini M. L., Nerva L., Mazza G., Seno M. \& Mori E., 2019 - Multiple origins of the common chameleon in southern Italy. Herpetozoa, 32: 11-19.

Bellati A., Bassu L., Nulchis V. \& Corti C., 2019 - Detection of alien Pelophylax species in Sardinia (Western Mediterranean, Italy). BioInvasions Records, 8 (1): 8-25.

Biello R., Zampiglia M., Corti C., Deli G., Biaggini M., Crestanello B., Delaugerre M., Di Tizio L., Leonetti F. L., Casari S., Olivieri O., Pellegrino F., Romano A., Sperone E., Hauffe H. C., TrabalzaMarinucci M., Bertorelle G., \& Canestrelli D. 2021 - Mapping the 
geographic origin of captive and confiscated Hermann's tortoises: A genetic toolkit for conservation and forensic analyses. Forensic Science International: Genetics, 51 (102447): 1-6.

Bischoff W., 1988 - Zur Verbreitung und Systematik der Zauneidechse, Lacerta agilis Linnaeus, 1758. Mertensiella, 1: 11-30.

Bisconti R., Porretta D., Arduino P., Nascetti G. \& Canestrelli D., 2018 Hybridization and extensive mitochondrial introgression among fire salamanders in peninsular Italy. Scientific Reports, 8 (13187): $1-10$.

Calmonte T. \& Ferri V., 1987 - Un serpente nuovo per la fauna italiana: il colubro scalare Elaphe scalaris (Schinz, 1822). Atti Società italiana di Scienze naturali e del Museo civico di Storia naturale di Milano, 128 (3/4): 314-316.

Canestrelli D. \& Nascetti G., 2008 - Phylogeography of the pool frog Rana (Pelophylax) lessonae in the Italian peninsula and Sicily: multiple refugia, glacial expansions and nuclear-mitochondrial discordance. Journal of Biogeography, 35: 1923-1936.

Capra F., 1954 - La Vipera berus L. in Piemonte. Annali del Museo Civico di Storia Naturale "G. Doria”, Genova, 66-67: 301-312.

Capula M., 1994a - Evolutionary relationships of Podarcis lizards from Sicily and the Maltese Islands. Journal of Zoological Systematics and Evolutionary Research, 32: 180-192.

Capula M., 1994b - Genetic variation and differentiation in the lizard, Podarcis wagleriana (Reptilia: Lacertidae). Biological Journal of the Linnean Society, 52: 177-196.

Capula M., 2004 - Low genetic variation in a critically endangered Mediterranean lizard: conservation concerns for Podarcis raffonei. Italian Journal of Zoology, 71 (Suppl. 1): 161-166.

Caputo V., 1993 - Taxonomy and evolution of the Chalcides chalcides complex with description of two new species. Bollettino del Museo regionale di Scienze naturali, Torino, 11 (1): 47-120.

Carlino P. \& Pauwels O. S. G., 2016 - Taxonomic identity of an extralimital population of Algyroides (Squamata: Lacertidae) from Apulia region in southern Italy. Bulletin of the Chicago Herpetological Society, 51 (9): 149-151.

Carranza S., Arnold E. N. \& Pleguezuelos J. M., 2006 - Phylogeny, biogeography, and evolution of two Mediterranean snakes, Malpolon monspessulanus and Hemorrhois hippocrepis (Squamata, Colubridae), using mtDNA sequences. Molecular Phylogenetics and Evolution, 40: 532-546.

Carranza S., Romano A., Arnold E. N. \& Sotgiu G., 2008 - Biogeography and evolution of European cave salamanders, Hydromantes (Urodela: Plethodontidae), inferred from mtDNA sequences. Journal of Biogeography, 35 (4): 724-738.

Carretero M. A., Perera A., Lo Cascio P. \& Harris D. J., 2009 - Unexpected phylogeographic affinities of Psammodromus algirus from Conigli islet (Lampedusa). Acta Herpetologica, 4 (1): 1-6.

Castiglia R., Senczuk G., Böhme W. \& Corti C., 2021 - In "defense" of Podarcis latastei, an Italian insular endemic species (Squamata: Lacertidae). Amphibia-Reptilia, [advance paper]: 1-5. <https://doi. org/10.1163/15685381-bja10047>

Chiocchio A., Bisconti R., Zampiglia M., Nascetti G., \& Canestrelli, D. 2017 - Quaternary history, population genetic structure and diversity of the cold-adapted Alpine newt Ichthyosaura alpestris in peninsular Italy. Scientific reports, 7 (1): 1-12.

Cornetti L., Ficetola G. F., Hoban S. \& Vernesi C., 2015a - Genetic and ecological data reveal species boundaries between viviparous and oviparous lizard lineages. Heredity, 115: 517-526.

Cornetti L., Belluardo F., Ghielmi S., Giovine G., Ficetola G. F., Bertorelle G., Vernesi C. \& Hauffe H. C., 2015b - Reproductive isolation between oviparous and viviparous lineages of the Eurasian common lizard Zootoca vivipara in a contact zone. Biological Journal of the Linnean Society, 114: 566-573.

Cossu I. M., Frau S., Delfino M., Chiodi A., Corti C. \& Bellati A., 2018 First report of Bufo bufo (Linnaeus, 1758) from Sardinia (Italy). Acta Herpetologica, 13 (1): 43-49.

Crescente A., Sperone E., Paolillo G., Bernabò I., Brunelli E. \& Tripepi S., 2014 - Nesting ecology of the exotic Trachemys scripta elegans in an area of Southern Italy (Angitola Lake, Calabria). AmphibiaReptilia, 35 (3): 366-370.

Crottini A., Andreone F., Kosuch J., Borkin L. J., Litvinchuk S. N., Eggert C. \& Veith M., 2007 - Fossorial but widespread: the phylo- geography of the common spadefoot toad (Pelobates fuscus), and the role of the Po Valley as a major source of genetic variability. Molecular Ecology, 2007: 1-21.

Dayrat B., 2005 - Towards integrative taxonomy. Biological Journal of the Linnean Society, 85 (3): 407-417.

Dubois A., 2007 - Naming taxa from cladograms: A cautionary tale. Molecular Phylogenetics and Evololution, 42 (2): 317-330.

Dubois A. \& Bour R., 2010 - The nomenclatural status of the nomina of amphibians and reptiles created by Garsault (1764), with a parsimonious solution to an old nomenclatural problem regarding the genus Bufo (Amphibia, Anura) and comments on some nomina created by Laurenti (1768). Zootaxa, 2447: 1-52.

Domeneghetti D., Bruni G., Fasola M. \& Bellati A., 2013 - Discovery of alien water frogs (gen. Pelophylax) in Umbria, with the first report of P. shqipericus for Italy. Acta Herpetologica, 8 (2): 171-176.

Doniol-Valcroze P., Ursenbacher S., Mebert K., Ghielmi S., Laddaga L., Sourrouille P., Kariș M. \& Crochet P.-A., 2021 - Conflicting relationships of Vipera walser inferred from nuclear genes sequences and mitochondrial DNA. Journal of Zoological Systematics and Evolutionary Research. $<$ https://doi.org/10.1111/jzs.12543>

Dufresnes C., Bonato L., Novarini N., Betto-Colliard C., Perrin N. \& Stöck M., 2014 - Inferring the degree of incipient speciation in secondary contact zones of closely related lineages of Palearctic green toads (Bufo viridis subgroup). Heredity, 113: 9-20.

Dufresnes C., Strachinis I., Tzoras E., Litvinchuk S. N. \& Denoël M., 2019 - Call a spade a spade: taxonomy and distribution of Pelobates, with description of a new Balkan endemic. ZooKeys, 859: 131-158.

Faraone F. P., Barraco L., Giacalone G., Muscarella C., Schifani E. \& Vecchioni L., 2019 - First records of the Brahminy blind snake, Indotyphlops braminus (Daudin, 1803) (Squamata: Typhlopidae), in Italy. Herpetology Notes, 12: 1225-1229.

Faraone F. P., Melfi R., Di Nicola M. R., Giacalone G. \& Lo Valvo M., $2020 \mathrm{a}$ - The genetic identity of the only Italian population of the genus Macroprotodon Guichenot, 1850 on the island of Lampedusa, Sicily. Vertebrate Zoology, 70 (2): 235-240.

Faraone F. P., Melfi R., Di Nicola M. R., Giacalone G. \& Lo Valvo M., $2020 \mathrm{~b}$ - Phylogenetic relationships of the Italian populations of Horseshoe Whip Snake Hemorrhois hippocrepis (Serpentes, Colubridae). Acta Herpetologica, 15 (2): 129-135.

Ferri V. \& Soccini C., 2010 - Prima segnalazione di riproduzione di Trachemys scripta scripta in condizioni seminaturali nell'Alto Lazio (Italia Centrale). In: Atti VIII Congresso Nazionale Societas Herpetologica Italica (Chieti, 22-26 settembre 2010). Di Tizio L., Di Cerbo A. R., Di Francesco N., Cameli A. (eds.). Ianieri Edizioni, Pescara: 359-362.

Ficetola G. F., Monti A. \& Padoa-Schioppa E., 2003 - First record of reproduction of Trachemys scripta in the Po Delta. Annali del Museo civico di Storia naturale di Ferrara, 5: 125-128.

Fijarczyk A., Nadachowska K., Hofman S., Litvinchuk S. N., Babik W., Stuglik M., Gollmann G., Choleva L., Cogalniceanu D., Vukov T., Džukić G. \& Szymura J. M., 2011 - Nuclear and mitochondrial phylogeography of the European fire-bellied toads Bombina bombina and Bombina variegata supports their independent histories. Molecular Ecology, 20: 3381-2298.

Freitas I., Ursenbacher S., Mebert K., Zinenko O., Schweiger S., Wüster W., Brito J. C., Crnobrnja-Isailovic J., Halpern B., Fahd S., Santos X., Pleguezuelos J. M., Joger U., Orlov N., Mizsei E., Lourdais O., Zuffi M. A. L., Strugariu A., Zamfirescu S. R., Martínez-Solano Í., Velo-Antón G., Kaliontzopoulou A. \& Martínez-Freiría F., 2020 Evaluating taxonomic inflation: towards evidence-based species delimitation in Eurasian vipers (Serpentes: Viperinae). Amphibia-Reptilia, 41 (3): 285-311. <https://doi.org/10.1163/15685381-bja10007>

Fritz U., Harris D. J., Fahd S., Rouag R., Graciá Martínez E., Giménez Casalduero A., Kalboussi M., Jdeidi T. B. \& Hundsdörfer A. K., 2009 - Mitochondrial phylogeography of Testudo graeca in the Western Mediterranean: old complex divergence in North Africa and recent arrival in Europe. Amphibia-Reptilia, 30: 63-80.

Fritz U. \& Schmidtler J. F. 2020 - The Fifth Labour of Heracles: Cleaning the Linnean stable of names for grass snakes (Natrix astreptophora, N. helvetica, N. natrix sensu stricto). Vertebrate Zoology, 70 (4): 621-665. 
Frost D. R., 2020 - Amphibian Species of the World: an Online Reference. Version 6.1 (27 June 2020). Electronic Database accessible athttps:// amphibiansoftheworld.amnh.org/index.php. American Museum of Natural History, New York, USA. < doi.org/10.5531/db.vz.0001>

Ghielmi S., Menegon M., Marsden S. J., Laddaga L. \& Ursenbacher S., 2016 - A new vertebrate for Europe: the discovery of a rangerestricted relict viper in the western Italian Alps. Journal of Zoological Systematics and Evolutionary Research, 54 (3): 161-173.

Giovannotti M., Nisi Cerioni P. \& Caputo F. P., 2010 - Mitochondrial DNA sequence analysis reveals multiple Pleistocene glacial refugia for Podarcis muralis (Laurenti, 1768) in the Italian Peninsula. Italian Journal of Zoology, 77 (3): 277-288.

Gorički Š. \& Trontelj P., 2006 - Structure and evolution of the mitochondrial control region and flanking sequences in the European cave salamander Proteus anguinus. Gene, 378: 31-41.

Gorički Š., Stanković D., Snoj A., Kuntner M., Jeffery W. R., Trontelj P., Pavićević M., Grizelj Z., Năpăruş-Aljančič M. \& Aljančič G., 2017 - Environmental DNA in subterranean biology: range extension and taxonomic implications for Proteus. Scientific Reports, 7 (45054): 1-11.

Gorman G. C., Soulé M., Yang S. Y. \& Nevo E., 1975 - Evolutionary genetics of insular Adriatic lizards. Evolution, 29: 52-71.

Gvoždík V., Benkovský N., Crottini A., Bellati A., Moravec J., Romano A., Sacchi R. \& Jandzik D., 2013 - An ancient lineage of slow worms, genus Anguis (Squamata: Anguidae), survived in the Italian Peninsula. Molecular Phylogenetics and Evolution, 69 (3): 10771092.

Gvoždík V., Benkovský N., Crottini A., Bellati A., Moravec J., Romano A., Sacchi R., Jandzik D., 2013 [in press] - An ancient lineage of slow worms, genus Anguis (Squamata: Anguidae), survived in the Italian Peninsula. Molecular Phylogenetics and Evolution, 2013: $1-16+1-4$.

Harris D. J., Carretero M. A., Corti C. \& Lo Cascio P., 2009 - Genetic affinities of Tarentola mauritanica (Reptilia: Gekkonidae) from Lampedusa and Conigli islet (SW Italy). North-Western Journal of Zoology, 5 (1): 197-205.

Hofman S., Spolsky C., Uzzell T., Cogălniceanu D., Babik W. \& Szymura J. M., 2007 - Phylogeography of the fire-bellied toads Bombina: independent Pleistocene histories inferred from mitochondrial genomes. Molecular Ecology, 16: 2301-2316.

Horreo J. L., Pelaez M. L., Suárez T., Breedveld M. C., Heulin B., Surget-Groba Y., Oksanen T. A. \& Fitze P. S., 2018 - Phylogeography, evolutionary history and effects of glaciations in a species (Zootoca vivipara) inhabiting multiple biogeographic regions. Journal of Biogeography, 45 (7): 1616-1627. <https://doi.org/10.1111/ jbi.13349>

ICZN - International Commission on Zoological Nomenclature, 1957 Opinion 490. Action under the plenary powers to preserve for use in its accustomed sense the generic name "Elaphe" Fitzinger 1833 (Class Reptilia). International Trust for Zoological Nomenclature, London, 17 (12): 181-196.

ICZN - International Commission on Zoological Nomenclature, 1987aOpinion 1461. A ruling on the authorship and dates of the text volumes of the Histoire naturelle section of Savigny's Description de l'Egypte. Bulletin of Zoological Nomenclature, 44 (3): 219-220.

ICZN - International Commission on Zoological Nomenclature, 1987b Opinion 1463. De Lacépède, 1788-1789, Histoire Naturelle des Serpents and later editions: rejected as non binominal work. Bulletin of Zoological Nomenclature, 44 (4): 265-267.

ICZN - International Commission on Zoological Nomenclature, 1999 International code of zoological nomenclature. International Trust for Zoological Nomenclature, London.

Insacco G. \& Spadola F. 2010 - First record of Kemp's ridley sea turtle, Lepidochelys kempii (Garman, 1880) (Cheloniidae), from the Italian waters (Mediterranean Sea). Acta Herpetologica, 5 (1): 113117.

Isaac N. J. B., Mallet J. \& Mace G., 2004 - Taxonomic inflation: its influence on macroecology and conservation. Trends in Ecology \& Evolution, 19 (9): 464-469.

Jablonski D., Nagy Z. T., Avcı A., Olgun K., Kukushkin O. V., SafaeiMahroo B. \& Jandzik D., 2019 - Cryptic diversity in the smooth snake (Coronella austriaca). Amphibia-Reptilia, 40 (2): 179-192.
Kalyabina S. A., Milto K. D., Anan'jeva N. B., Legal L., Joger U. \& Wink M., 2001 - Phylogeography and systematics of Lacerta agilis based on the mitochondrial cytochrome $\mathrm{b}$ gene sequences: first results. Russian Journal of Herpetology, 8 (2): 149-158.

Kindler C., Chèvre M., Ursenbacher S., Bohme W., Hille A., Jablonski D., Vamberger M. \& Fritz U., 2017 - Hybridization patterns in two contact zones of grass snakes reveal a new Central European snake species. Scientific Reports, 7: 7378. <https://doi.org/10.1038/ s41598-017-07847-9>

Kindler C. \& Fritz U., 2018 - Phylogeography and taxonomy of the barred grass snake (Natrix helvetica), with a discussion of the subspecies category in zoology. Vertebrate Zoology, 68 (3): 253-267.

Kotsakiozi P., Jablonski D., Ilgaz Ç., Kumlutaş Y., Avc1 A., Meiri S., Itescu Y., Kukushkin O., Gvoždík V., Scillitani G., Roussos S. A., Jandzik D., Kasapidis P., Lymberakis P. \& Poulakakis N., 2018 Multilocus phylogeny and coalescent species delimitation in Kotschy's gecko, Mediodactylus kotschyi: Hidden diversity and cryptic species. Molecular Phylogenetics and Evolution, 125: 177-187+ suppl. 1 (15 pp.) + suppl. 2 (9 pp.).

Lanza B., 1983 - Guide per il riconoscimento delle specie animali nelle acque interne italiane. 27. Anfibi, Rettili (Amphibia, Reptilia). Collana del Progetto Finalizzato "Promozione della Qualità dell'Ambiente" AQ/1/205, Consiglio Nazionale delle Ricerche, Roma.

Laurenti J. N., 1768 - Synopsin reptilium emendatam cum experimentis circa venena et antidota reptilium austriacorum. Joannis Thomae nob. de Trattnern, Vienna.

Lillo F., Dufresnes C., Faraone F. P., Lo Valvo M., Stöck M., 2013 Identification and potential origin of invasive clawed frogs Xenopus (Anura: Pipidae) in Sicily based on mitochondrial and nuclear DNA. Italian Journal of Zoology, 80 (4): 566-573.

Litvinchuk S. N., Crottini A., Federici S., De Pous P., Donaire D., Andreone F., Kalezić M. L., Džukić G., Lada G. A., Borkin L. J. \& Rosanov J. M., 2013 - Phylogeographic patterns of genetic diversity in the common spadefoot toad, Pelobates fuscus (Anura: Pelobatidae), reveals evolutionary history, postglacial range expansion and secondary contact. Organisms Diversity and Evolution, 13: 433-451.

Luiselli L., Corti C., Salvi D. \& Capula M., 2010 [2011] - Hemorrhois hippocrepis. In: Fauna d'Italia, vol. XLV, Reptilia. Corti C., Capula M., Luiselli L., Sindaco R., Razzetti E. (eds.). Calderini, Bologna, 499-504.

Manfredi T., Bellavita M., Ottonello D., Zuffi M. A. L., Carlino P., Chelazzi G., D’Angelo S., Di Tizio L., Fritz U., Lo Valvo M., Marini G., Orrù F., Scali S., Sperone E. \& Ciofi C., 2013 - Filogeografia delle popolazioni italiane della testuggine palustre europea Emys orbicularis basata su analisi di sequenza del DNA mitocondriale e loci microsatelliti. In: Atti II Congresso SHI Abruzzo Molise "Testuggini e Tartarughe" (Chieti, 27-29 settembre 2013). Di Tizio L., Brugnola L., Cameli A., Di Francesco N. (eds.). Ianieri Edizioni, Pescara: 31-39.

Marzhan E., Mayer W., Joger U., Ilgaz Ç., Jablonski D., Kindler C., Kumlutaş Y., Nistri A., Schneeweiss N., Vamberger M., Žagar A. \& Fritz U., 2016 - Phylogeography of the Lacerta viridis complex: mitochondrial and nuclear markers provide taxonomic insights. Journal of Zoological Systematics and Evolutionary Research, 54 (2): 85-105.

Mattoccia M., Romano A. \& Sbordoni V., 2005 - Mitochondrial DNA sequences analysis of the spectacled salamander, Salamandrina terdigitata, supports the existence of two distinct species. Zootaxa, 995: 1-19.

Mezzasalma M., dall'Asta A., Loy A., Cheylan M., Lymberakis P., Zuffi M. A. L., Tomović L., Odierna G. \& Guarino F. M., 2015 A sisters' story: comparative phylogeography and taxonomy of Hierophis viridiflavus and H. gemonensis (Serpentes, Colubridae). Zoologica Scripta, 44: 495-508.

Moravec J., Kratochvíl L., Amr Z. S., Jandzik D., Šmíd J., Gvoždík V., 2011 - High genetic differentiation within the Hemidactylus turcicus complex (Reptilia: Gekkonidae) in the Levant, with comments on the phylogeny and systematics of the genus. Zootaxa, 2894 (1): 21-38.

Pabijan M., Zieliński P., Dudek K., Chloupek M., Sotiropoulos K., Liana M. \& Babik W., 2015 - The dissection of a Pleistocene refu- 
gium: phylogeography of the smooth newt, Lissotriton vulgaris, in the Balkans. Journal of Biogeography, 42 (4): 671-683.

Pabijan M., Zielinski P., Dudek K., Stuglik M. \& Babik W., 2017 - Isolation and gene flow in a speciation continuum in newts. Molecular Phylogenetics and Evolution, 116: 1-12.

Palo J. U., Lesbarreres D., Schmeller D. S., Primmer C. R. \& Merilä J., 2004 - Microsatellite marker data suggest sex-biased dispersal in the common frog Rana temporaria. Molecular Ecology, 13 (9): 2865-2869.

Paolino G., Scotti R. \& Grano M., 2019 - First detection of the "flowerpot snake" Indotyphlops braminus (Daudin, 1803) (Serpentes Typhlopidae) in Ischia (Italy): a new possible invasive species. Biodiversity Journal, 10 (4): 321-324.

Parenti P. \& Randall J. E., 2000 - An annotated checklist of the species of the Labroid fish families Labridae and Scaridae. Ichthyological Bulletin of the J.L.B. Smith Institute of Ichthyology, 68: 1- 97.

Pedall I., Fritz U., Stuckas H., Valdeon A. \& Wink M., 2010 - Gene flow across secondary contact zones of the Emys orbicularis complex in the Western Mediterranean and evidence for extinction and re-introduction of pond turtles on Corsica and Sardinia (Testudines: Emydidae). Journal of Zoological Systematics and Evolutionary Research, 49 (1): 44-57.

Perez M., Livoreil B., Mantovani S., Boisselier M.-C., Crestanello B., Abdelkrim J., Bonillo C., Goutner V., Lambourdière J., Pierpaoli M., Sterijovski B., Tomovic L., Vilaça S. T., Mazzotti S. \& Bertorelle G., 2014 - Genetic variation and population structure in the endangered Hermann's tortoise: the roles of geography and humanmediated processes. Journal of Heredity, 105 (1): 70-81.

Podnar M. \& Mayer W., 2005 - Can mitochondrial DNA draw the phylogenetic picture of Central Mediterranean island Podarcis? Herpetozoa, 18 (1/2): 73-77.

Podnar M., Mayer W. \& Tvrtkovic N., 2004 - Mitochondrial phylogeography of the Dalmatian wall lizard, Podarcis melisellensis (Lacertidae). Organism Diversity and Evolution, 4: 307-317.

Podnar M., Mayer W. \& Tvrtkovic N., 2005 - Phylogeography of the Italian wall lizard, Podarcis sicula, as revealed by mitochondrial DNA sequences. Molecular Ecology, 14: 575-588.

Rato C., Zuffi M., Corti C., Fornasiero S., Gentilli A., Razzetti E., Scali S., Carretero M. A. \& Harris D. J. 2009 - Phylogeography of the European Whip Snake, Hierophis viridiflavus (Colubridae), using mtDNA and nuclear DNA sequences. Amphibia-Reptilia, 30 (2): 283-289.

Razzetti E., Andreone F., Corti C. \& Sindaco R., 2006 - 5. Checklist of the Italian herpetofauna with taxonomic remarks. / 5. Checklist dell'erpetofauna italiana e considerazioni tassonomiche. In: Atlante degli Anfibi e dei Rettili d'Italia. / Atlas of Italian Amphibians and Reptiles. Sindaco R., Doria G., Razzetti E. \& Bernini F. (eds.). Societas Herpetologica Italica, Edizioni Polistampa: 148-177.

Recuero E., Iraola A., Rubio X., Machordom A. \& García-París M., 2007 - Mitochondrial differentiation and biogeography of Hyla meridionalis (Anura: Hylidae): an unusual phylogeographical pattern. Journal of Biogeography, 34: 1207-1219.

Recuero E., Canestrelli D., Vörös J., Szabó K., Poyarkov N. A., Arntzen J. W., Crnobrnja-Isailovic J., Kidovh A. A., Cogălniceanu D., Caputo F. P. \& Nascetti G., 2012 - Multilocus species tree analyses resolve the radiation of the widespread Bufo bufo species group (Anura, Bufonidae). Molecular Phylogenetics and Evolution, 62 (1): 71-86.

Recuero E., Buckley D., García-París M., Arntzen J. W., Cogălniceanu D. \& Martínez-Solano I., 2014 - Evolutionary history of Ichthyosaura alpestris (Caudata, Salamandridae) inferred from the combined analysis of nuclear and mitochondrial markers. Molecular Phylogenetics and Evolution, 81: 207-220.

Rodríguez V., Brown R. P., Terrasa B., Pérez-Mellado V., Picornell A., Castro J. A. \& Ramon C., 2014 - Genetic diversity and historical biogeography of the Maltese wall lizard, Podarcis filfolensis (Squamata: Lacertidae). Conservation Genetics, 15 (2): 295-304.

Romano A., Mattoccia M., Marta S., Bogaerts S., Pasmans F., \& Sbordoni V., 2009 - Distribution and morphological characterization of the endemic Italian salamanders Salamandrina perspicillata (Savi, 1821 ) and S. terdigitata (Bonnaterre, 1789) (Caudata: Salamandridae). Italian Journal of Zoology, 76: 422-432.
Ruggi A., 2007 - Descrizione di una zona di contatto e ibridazione tra Speleomantes italicus e S. ambrosii bianchii (Amphibia: Plethodontidae) sulle Alpi Apuane, mediante marcatori nucleari e mitocondriali. Università degli Studi della Tuscia, Viterbo. $<\mathrm{https} / /$ dspace.unitus.it/handle/2067/240>

Salvi D., Bombi P., Corti C. \& Bologna M. A., 2008 - Pattern of morphometric variation in Archaeolacerta bedriagae (Reptilia: Lacertidae) employing in vivo and museum data. In: Herpetologia Sardiniae. C. Corti (ed.). Societas Herpetologica Italica / Edizioni Belvedere, Latina: 431-434.

Salvi D., Capula M., Bombi P. \& Bologna M. A., 2009 - How many Archaeolacerta inhabit the Corso-Sardinian Plate? Allozyme variation and differentiation in Archaeolacerta bedriagae (Camerano, 1885). Amphibia-Reptilia, 30: 463-470.

Salvi D., Harris D. J., Bombi P., Carretero M. A. \& Bologna M. A., 2010 - Mitochondrial phylogeography of the Bedriaga's rock lizard, Archaeolacerta bedriagae (Reptilia: Lacertidae) endemic to Corsica and Sardinia. Molecular Phylogenetics and Evolution, 56 (2): 690-697.

Salvi D., Harris D. J., Kaliontzopoulou A., Carretero M. A. \& Pinho C., 2013 - Persistence across Pleistocene ice ages in Mediterranean and extra-Mediterranean refugia: phylogeographic insights from the common wall lizard. BMC Evolutionary Biology, 13: 1-18.

Salvi D., Schembri P. J., Sciberras A. \& Harris D. J., 2014 - Evolutionary history of the Maltese wall lizard Podarcis filfolensis: insights on the 'Expansion-Contraction' model of Pleistocene biogeography. Molecular Ecology, 23: 1167-1187.

Salvi D., Lucente D., Mendes J., Liuzzi C., Harris D. J. \& Bologna M. A., 2017 - Diversity and distribution of the Italian Aesculapian snake Zamenis lineatus: a phylogeographic assessment with implications for conservation. Journal of Zoological Systematics and Evolutionary Research, 55: 222-237.

Salvi D., Mendez J., Carranza S. \& Harris J.D., 2018 - Evolution, biogeography and systematics of the western Palaearctic Zamenis ratsnakes. Zoologica Scripta, 47: 441-461.

Salvi D., Pinho C., Mendes J. \& Harris D. J., 2021 - Fossil-calibrated time tree of Podarcis wall lizards provides limited support for biogeographic calibration models. Molecular Phylogenetics and Evolution: 161 (107169): 1-16.

Santos X., Roca J., Pleguezuelos J. M., Donaire D. \& Carranza S., 2008 - Biogeography and evolution of the smooth snake Coronella austriaca (Serpentes: Colubridae) in the Iberian Peninsula: evidence for Messinian refuges and Pleistocenic range expansions. Amphibia-Reptilia, 29: 35-47.

Schmidtler J. F., 2019 - Zur postglazialen Einwanderung heimischer Amphibien und Reptilien: Zoogeografische, ökologische und taxonomische Aspekte. In: Amphibien und Reptilien in Bayern. Andrä E., Aßmann O., Dürst T., Hansbauer G. \& Zahn A. (eds). Verlag Eugen Ulmer, Stuttgart: 40-50.

Schmidtler J. F. \& Böhme W., 2011 - Synonymy and nomenclatural history of the common or viviparous lizard, by this time: Zootoca vivipara (Lichtenstein, 1823). Bonn zoological Bulletin, 60 (2): 145-159.

Schultze N., Spitzweg C., Corti C., Delaugerre M., Di Nicola M. R., Geniez P., Lapini L., Liuzzi C., Lunghi E., Novarini N., Picariello O., Razzetti E., Sperone E., Stellati L., Vignoli L., Asztalos M., Kindler C., Vamberger M. \& Fritz U., 2020 - Mitochondrial ghost lineages blur phylogeography and taxonomy of Natrix helvetica and N. natrix in Italy and Corsica. Zoologica Scripta, 49: 395-411.

Senczuk G., Colangelo P., De Simone E., Aloise G. \& Castiglia R., 2017 - A combination of long-term fragmentation and glacial persistence drove the evolutionary history of the Italian wall lizard Podarcis siculus. BMC Evolutionary Biology, 17 (6): 1-15.

Senczuk G., Havenstein K., Milana V., Ripa C., De Simone E., Tiedemann R., \& Castiglia R. 2018 - Spotlight on islands: on the origin and diversification of an ancient lineage of the Italian wall lizard Podarcis siculus in the western Pontine Islands. Scientific reports, 8(1): 1-12.

Senczuk G., Castiglia R., Böhme W. \& Corti C., 2019 - Podarcis siculus latastei (Bedriaga, 1879) of the Western Pontine Islands (Italy) raised to the species rank, and a brief taxonomic overview of Podarcis lizards. Acta Herpetologica, 14 (2): 71-80. <https://doi. org/10.13128/a_h-7744> 
Silva-Rocha I., Salvi D. \& Carretero M. A., 2012 - Genetic data reveal a multiple origin for the populations of the Italian wall lizard Podarcis sicula (Squamata: Lacertidae) introduced in the Iberian Peninsula and Balearic Islands. Italian Journal of Zoology, 79 (4): 502-510.

Sindaco R., Doria G., Razzetti E. \& Bernini F., 2006 - Atlante degli Anfibi e dei Rettili d'Italia. / Atlas of Italian Amphibians and Reptiles. Societas Herpetologica Italica. Edizioni Polistampa, Firenze.

Šmíd J., Moravec J., Zawadzki M. \& Van den Berg M., 2015 - One subspecies less for the European herpetofauna: the taxonomic and nomenclatural status of Hemidactylus turcicus spinalis (Reptilia: Gekkonidae). Zootaxa, 3911 (3): 443-446.

Sotiropoulos K., Eleftherakos K., Džukić G., Kalezić M. L., Legakis A. \& Polymeni R.-M., 2007 - Phylogeny and biogeography of the alpine newt Mesotriton alpestris (Salamandridae, Caudata), inferred from mtDNA sequences. Molecular Phylogenetics and Evolution, 45: 211-226.

Speybroeck J., Beukema W. \& Crochet P. A., 2010 - A tentative species list of the European herpetofauna (Amphibia and Reptilia) - an update. Zootaxa, 2492 (1): 1-27.

Speybroeck J., Beukema W., Dufresnes C., Fritz U., Jablonski D., Lymberakis P., Martínez-Solano I., Razzetti E., Vamberger M., Vences M., Vörös J. \& Crochet P-A., 2020 - Species list of the European herpetofauna - update by the Taxonomic Committee of the Societas Europaea Herpetologica. Amphibia-Reptilia, 41 (2): 139-189.

Stefani F., Gentilli A., Sacchi R., Razzetti E., Pellitteri-Rosa D., Pupin F. \& Galli P., 2012 - Refugia within refugia as a key to disentangle the genetic pattern of a highly variable species: the case of Rana temporaria Linnaeus, 1758 (Anura, Ranidae). Molecular Phylogenetics and Evolution, 65: 718-726.

Stöck M., Grifoni G., Armor N., Scheidt U., Sicilia A. \& Novarini N., 2016 - On the origin of the recent herpetofauna of Sicily: comparative phylogeography using homologous mitochondrial and nuclear genes. Zoologischer Anzeiger, 261: 70-81.

Teacher A. G. F., Garner T. W. J. \& Nichols R. A., 2009 - European phylogeography of the common frog (Rana temporaria): routes of postglacial colonization into the British Isles, and evidence for an Irish glacial refugium. Heredity, 102 (5): 490-496.

Thorpe R. S., 1979 - Multivariate analysis of the population systematics of the ringed snake Natrix natrix (L.). Proceedings of the Royal Society of Edinburgh, 78: 1-62.

Thorpe R. S., 1980 - Microevolution and taxonomy of European reptiles with particular reference to the grass snake Natrix natrix and the wall lizards Podarcis sicula and P. melisellensis. Biological Journal of the Linnean Society, 14: 213-233.

Tlili W., Delaugerre M., Ouni R. \& Nouira S., 2012 - Distributional review of the genus Tarentola (Reptilia, Sauria) in Tunisia (North Africa). Herpetology Notes, 5: 485-492.

Tokar A. A., 1991 - [A revision of the subspecies structure of javelin sand boa, Eryx jaculus (Linnaeus, 1758) (Reptilia Boidae)]. Herpetological Researches, Leningrad, 1: 18-41. (in Russian)

Trontelj P., Douady C. J., Fišer C., Gibert J., Gorički Š., Lefebure T., Sket B. \& Zakšek V., 2009 - A molecular test for cryptic diversity in ground water: how large are the ranges of macro-stygobionts? Freshwater Biology, 54 (4): 727-744.

Ursenbacher S., Conelli A., Golay P., Monney J.-C., Zuffi M. A. L., Thiery G., Durand T. \& Fumagalli L., 2006 - Phylogeography of the asp viper (Vipera aspis) inferred from mitochondrial DNA sequence data: evidence for multiple Mediterranean refugial areas. Molecular Phylogenetics and Evolution, 38: 546-552.

Ursenbacher S., Schweiger S., Tomović L., Crnobrnja-Isailović J., Fumagalli L. \& Mayer W., 2008 - Molecular phylogeography of the nose-horned viper (Vipera ammodytes, Linnaeus (1758)): evidence for high genetic diversity and multiple refugia in the Balkan peninsula. Molecular Phylogenetics and Evolution, 46: 1116-1128.

van der Meijden A., Chiari Y., Mucedda M., Carranza S., Corti C. \& Veith M., 2009- Phylogenetic relationships of Sardinian cave salamanders, genus Hydromantes, based on mitochondrial and nuclear DNA sequence data. Molecular Phylogenetics and Evolution, 51: 399-404.
Vasconcelos R., Harris D. J., Carretero M. A., Pinho C., Corti C., Capula M., Bassu L., Spano G. \& Delauguerre M., 2006 - Genetic diversity within Corsican and Sardinian specimens of the Tyrrhenian Wall Lizard, Podarcis tiliguerta, estimated using mtDNA sequences. In: Mainland and insular lacertid lizards: a Mediterranean perspective. C. Corti, P. Lo Cascio, M. Biaggini (eds.). Firenze University Press: 199-207.

Veith M., Vences M., Vieites D. R., Nieto-Roman S. \& Palanca A. 2002 Genetic differentiation and population structure within Spanish common frogs (Rana temporaria complex; Ranidae, Amphibia). Folia Zoologica, Praha, 51 (4): 307-318.

Veith M., Kosuch J. \& Vences M., 2003 - Climatic oscillations triggered post-Messinian speciation of Western Palearctic brown frogs (Amphibia, Ranidae). Molecular phylogenetics and evolution, 26 (2): 310-327.

Veith M., Baumgart A., Dubois A., Ohler A., Galán P., Vieites D. R. \& Vences M., 2012 - Discordant patterns of nuclear and mitochondrial introgression in Iberian populations of the European common frog (Rana temporaria). Journal of Heredity, 103 (2): 240-249.

Vences M., Hauswaldt J. S., Steinfartz S., Rupp O., Goesmann A., Künzel S., Orozco-terWengel P., Vieites D. R., Nieto-Roman S., Haas S., Laugsch C., Gehara M., Bruchmann S., Pabijan M., Ludewig A. K., Rudert D., Angelini C., Borkin L. J., Crochet P. A., Crottini A., Dubois A., Ficetola G. F., Galán P., Geniez P., Hachtel M., Jovanovic O., Litvinchuk S. N., Lymberakis P. O. \& Smirnov N. A., 2013 - Radically different phylogeographies and patterns of genetic variation in two European brown frogs, genus Rana. Molecular Phylogenetics and Evolution, 68 (3): 657-670.

Verardi A., Canestrelli D. \& Nascetti G., 2009 - Nuclear and mitochondrial patterns of introgression between the parapatric European treefrogs Hyla arborea and H. intermedia. Annales Zoologici Fennici, 46: 247-258.

Vieites D. R., Min M.-S. \& Wake D. B., 2007 - Rapid diversification and dispersal during periods of global warming by plethodontid salamanders. Proceedings of the National Academy of Sciences of the United States of America, 104: 19903-19907.

Vieites D. R., Román S. N., Wake M. H. \& Wake D. B., 2011 - A multigenic perspective on phylogenetic relationships in the largest family of salamanders, the Plethodontidae. Molecular Phylogenetics and Evolution, 59: 623-635.

VV.AA., 2007 - Linee guida per l'immissione di specie faunistiche. Quaderni di Conservazione della Natura, Ministero dell'Ambiente. Istituto Nazionale della Fauna Selvatica, Bologna, 27.

Wielstra B., Duijm E., Lagler P., Lammers Y., Meilink W. R. M., Ziermann J. M. \& Arntzen J. W., 2014 - Parallel tagged amplicon sequencing of transcriptome-based genetic markers for Triturus newts with the Ion Torrent next-generation sequencing platform. Molecular Ecology Resources, 14 (5): 1080-1089. <https://doi. org/10.1111/1755-0998.12242>

Wielstra B., Salvi D. \& Canestrelli D., 2021 - Genetic divergence across glacial refugia despite interglacial gene flow in a crested newt. Evolutionary Biology, 48 (2): 17-26.

Yuan Z.-Y., Zhou W.-W., Chen X., Poyarkov J. N. A., Chen H.-M., Jang-Liaw N.-H., Chou W.-H., Matzke N. J., Iizuka K., Min M.-S., Kuzmin S. L., Zhang Y.-P., Cannatella D. C., Hillis D. M. \& Che J., 2016 - Spatiotemporal diversification of the true frogs (genus Rana): a historical framework for a widely studied group of model organisms. Systematic Biology, 65: 824-842.

Zangari F., Cimmaruta R. \& Nascetti G., 2006 - Genetic relationships of the western Mediterranean painted frogs based on allozymes and mitochondrial markers: evolutionary and taxonomic inferences (Amphibia, Anura, Discoglossidae). Biological Journal of the Linnean Society, 87: 515-536.

Zheng Y., Fu J. \& Li S., 2009 - Toward understanding the distribution of Laurasian frogs: a test of Savage's biogeographical hypothesis using the genus Bombina. Molecular Phylogenetics and Evolution, 52: $70-83$. 